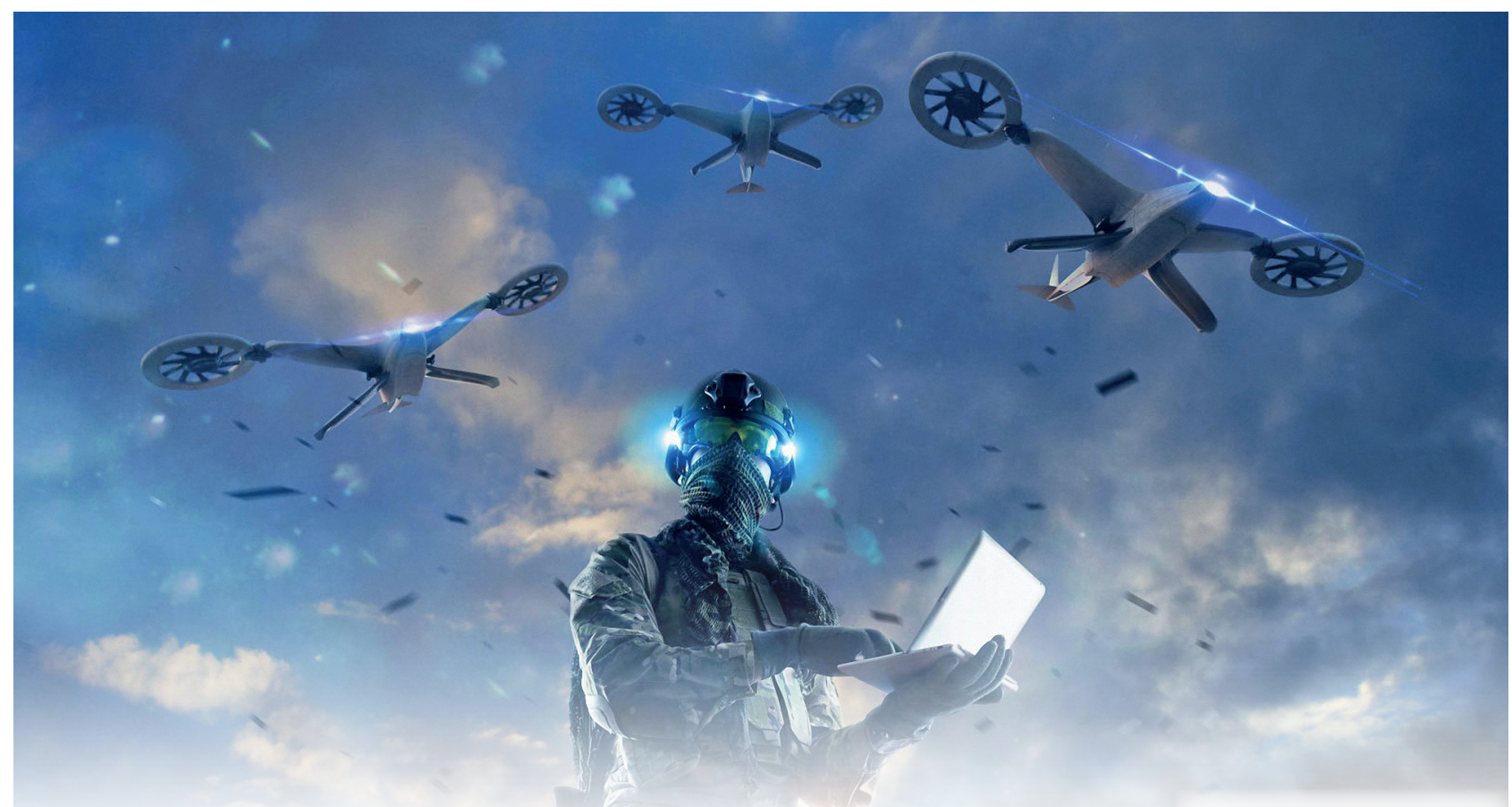

8. ábra. Drónrajtámadás

\title{
Mini UAV-rajok alkalmazásának lehetőségei, különös tekintettel a katonai célú igénybevételre m.ress
}

\section{SZÓRAKOZTATÓIPAR}

Napjainkban talán a szórakoztatóipar és látványtechnika területén található a legtöbb példa az UAV-rajok gyakorlati alkalmazására, annak köszönhetően, hogy ilyen jellegű feladatok többségének végrehajtása során lényegesen alacsonyabb szintű autonómia is elegendő a látványos eredmény eléréséhez. llyen esetlekben a raj tagjai egyszerű felépítésűek, fénykibocsátó diódákkal (LED - Light Emitting Diode) felszereltek, amelyek színe és intenzitása is változtatható. Ilyen SUAV-kból felépülő csoportok tetszőleges, dinamikusan változtatható alakzatokba szervezhetők, segítségükkel különböző formációkban 3D-s jelenetek hozhatók létre a levegőben, amelyek felbontása az alkalmazott egyedek számának függvénye. Ezeket nevezi a köznyelv „drónshow”-nak.

Az UAV-rajok ilyen célú hasznosítása alternatív megoldást kínál a drága, veszélyes és környezetszennyező pirotechnikai megoldások, tűzijátékok kiváltására, valamint nagyobb szabadságot biztosít a műsorokat tervező, rende- ző és megvalósító kreatív szakemberek számára. A közeljövőben ugyanakkor a reklámpiacon is megjelenhetnek hasonló megoldások, amelynek nyomán az égbolt válhat a legnagyobb reklámfelületté. A tanulmány megírásának időpontjában a kínai EHang cégé volt a Guinness-rekord a „legtöbb pilóta nélküli légijármű egyidejü levegőben tartózkodása" megnevezésű kategóriában, amelyet 2018. 04. 29-én Xi'an városa felett 1374 drón felhasználásával álítottak fel (9. ábra) [30].

\section{MeZöGAZdasÁG}

A 21. század egyik legnagyobb problémája a Föld túlnépesedése és az éghajlatváltozás okozta élelmiszerhiány, amire a mezőgazdasági technológiák fejlesztése jelenthet hatékony megoldást. Ezen a területen is komoly szerephez juthatnak a mini UAV-rajok alkalmazásán alapuló megoldások. A művelés alatt álló földterületeket a rajok egyedei

\footnotetext{
* Örnagy, egyetemi docens, NKE Hadtudományi és Honvédtisztképző Kar, Elektronikai Hadviselés Tanszék. ORCID: 0000-0003-2397-189X

** Hadnagy, MH Légi Vezetési és Irányítás Központ. ORCID: 0000-0002-9478-3418
} 


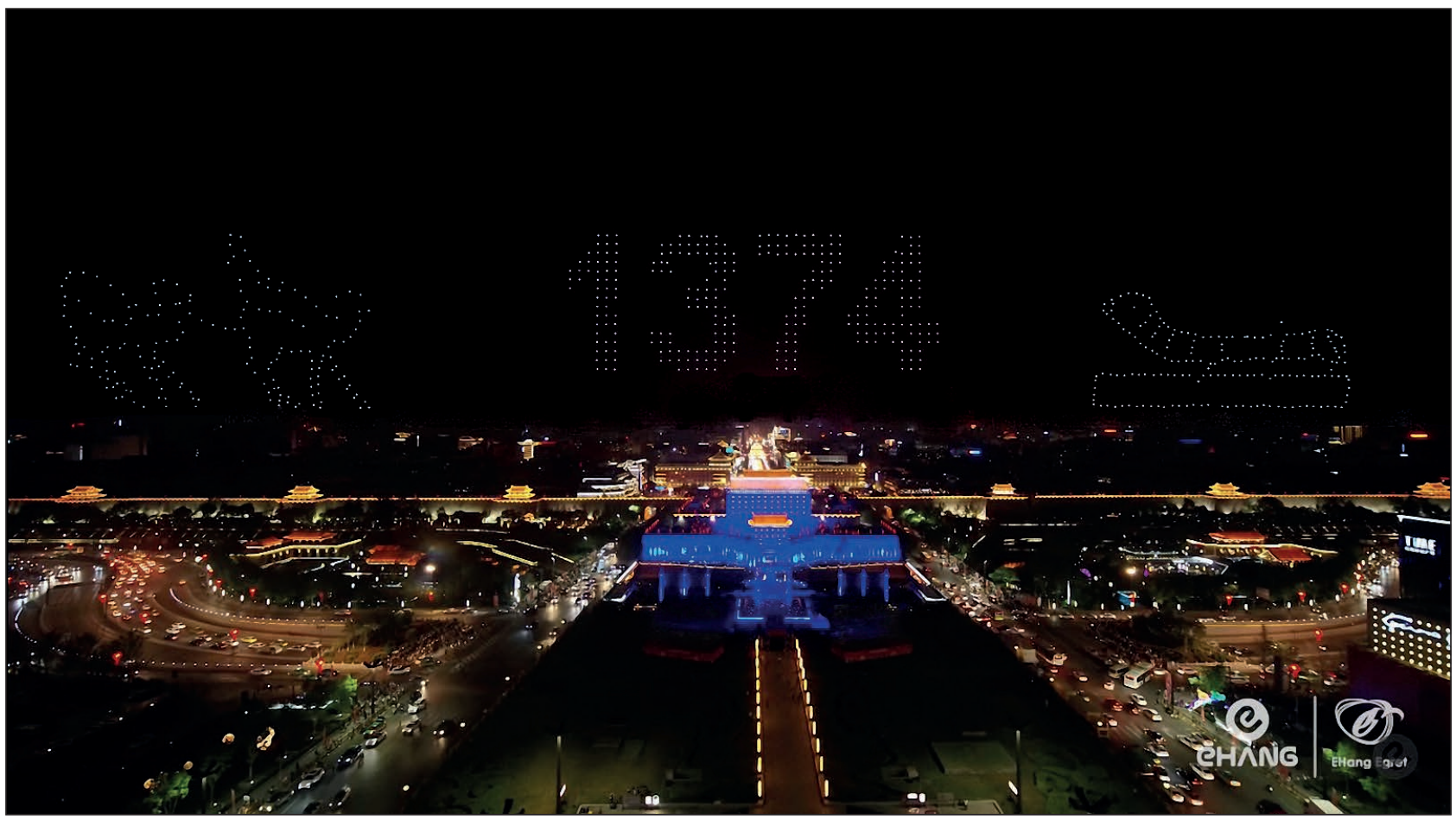

9. ábra. Az EHang cég sikeres világrekord kísérlete 1374 UAV reptetésével15

problémamentesen képesek újra és újra szisztematikusan berepülni, miközben szenzoraikkal, a geolokációs adatok pontos rögzítése mellett információt gyűjtenek a növények, illetve a termés pillanatnyi állapotáról (10. ábra). Az információ feldolgozása, kiértékelése és valamilyen geoinformációs (GIS - Geographical Information System) rendszerbe történő illesztése segítségével különböző eloszlási térképek készíthetők, amelyek alapján nyomon követhetők a bekövetkező változások, hely szerinti megoszlásban tervezhetők különböző, a termeléssel összefüggő műveletek (pl. növényvédelem, öntözés), megbecsülhető a termés várható mennyisége, minősége, a betakarítás optimális időszaka. Ezek alapján tervezhető a szükséges szállítási és tárolási kapacitás, optimalizálható a termelés, értékesítés és feldolgozás teljes folyamata. Már léteznek olyan koncepciók, amelyek szerint a drónok a mezőgazdasági területek mellett elhelyezett konténerekből felszállva teljesen autonóm módon képesek időszakosan kivitelezni a felszállási, repülési, információgyűjtési, leszállási, töltési és feldolgozási műveleteket, majd a kiértékelés eredményét továbbítani a központi szerverre, ahonnan a gazdálkodó bármikor és bárhonnan hozzáférhet azokhoz. Megfelelő érzékelők alkalmazásával lehetőség nyílik különböző növénybetegségek korai előrejelzésére is, megállapítva azok kiindulási és gócpontjait, így lehetőséget biztosítva a leghatékonyabb védekezési módok kiválasztására és kivitelezésére, a károk minimalizálására [31].

10. ábra. UAV-raj alkalmazásával végzett felmérések eredményei ${ }^{16}$

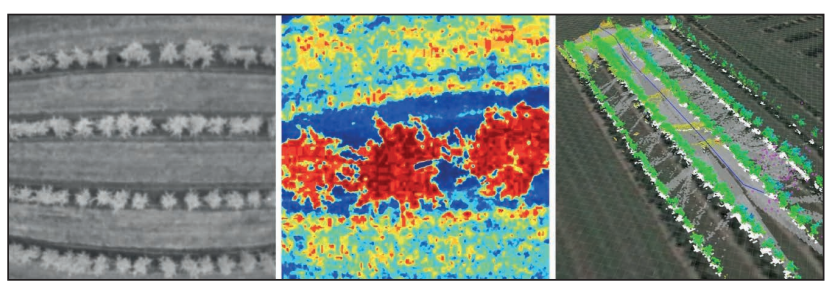

\section{BÜNÜLDÖZÉS, RENDVÉDELEM}

Bár a rendőrség már évtizedek óta használ helikoptereket, és az elmúlt években egyre nagyobb arányban UAV-ket is, a pilóta nélküli légijárműrajok alkalmazása új lehetőségeket kínál a bűnüldözés és rendvédelem területén. A rajok alkalmazása ezeken a területeken is gyorsabb reagálást, az egyedszámmal arányosan növekedő területek megfigyelését, átvizsgálását teszi lehetővé, alacsonyabb fajlagos költségek mellett. Bonyolult városi környezetben is biztonságosan és hatékonyan alkalmazhatók magas autonómiaszintjüknek, jó manőverező képességüknek köszönhetően, valamint az egyedek kis méretéből adódóan könnyedén képesek épületek között, vagy akár épületeken belül is (pl. stadionok, csarnokok) komplex feladatokat végrehajtani. Alkalmasak tömegrendezvények (pl. rockkoncertek, sportesemények, tüntetések) alkalmával pontos helyzetismeret biztosítására a rendőri erők számára, ilyen módon támogatva az esetleges beavatkozások, kiürítési feladatok ter-

\section{1. ábra. Rendőrségi UAV-ről infrakamerával készített} felvétel ${ }^{17}$

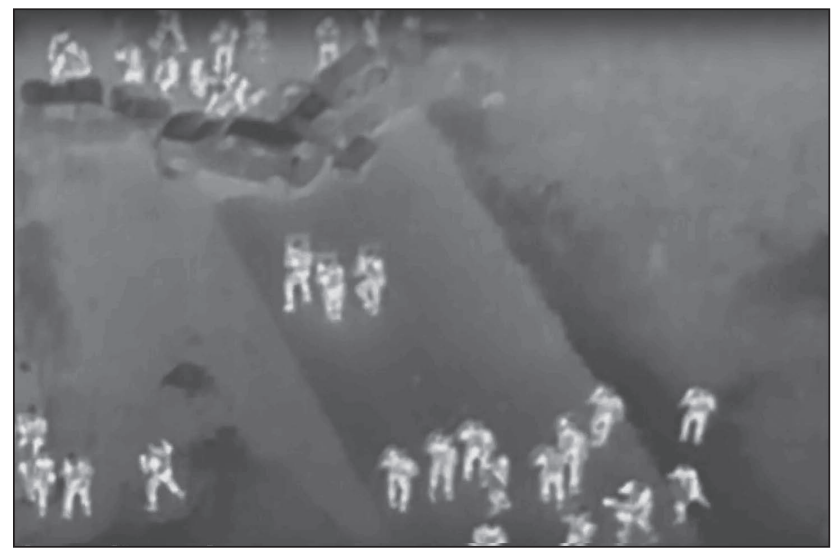


vezését, irányítását, de adott esetben segíthetnek a résztvevők tájékoztatásában, vagy ártó szándékú személyek lokalizálásában, a kiemelést megelőzően pedig figyelmének elterelésében, esetleg a helyszínt elhagyók követésében. A drónok, speciális szenzoraik segítségével rossz látási viszonyok között is nappal és éjszaka egyaránt képesek valós idejű képet szolgáltatni, ezzel is támogatva a rendőrség munkáját többek között például határőrizeti feladataik ellátása során, mint ahogyan az a 11. ábrán is látható. Ugyanakkor különböző arc-, illetve tevékenységelemző, -felismerő algoritmusok segítségével eltűnt, vagy körözött személyek felkutatása is lehetővé válik akár városi környezetben, tömegrendezvényeken, akár klasszikus kutatómentő (SR - Search and Rescue) feladatok során [32].

\section{MINI, PILÓTA NÉLKÜLI LÉGIJÁRMŰ RAJOK KATONAI CÉLÚ ALKALMAZÁSÁNAK LEHETŐSÉGEI}

Az általános alkalmazások során említett megoldások csaknem mindegyike hatékonyan felhasználható különböző katonai tevékenységek esetén is. Mini drónrajok alkalmazásával a harctér 3D-s modelljén folyamatosan nyomon követhető a saját és ellenséges csapatok, járművek és katonák tevékenysége, automatizált számítások végezhetők a tűztámogatáshoz szükséges paraméterek meghatározására, de lehetséges segítségükkel olyan elosztott paraméterü, redundáns, öngyógyító harctéri adatkommunikációs hálózat kialakítása is, amelyen keresztül a katonák és járművek szenzorrendszerei által szolgáltatott információk alapján, nyomon követhető aktuális egészségi, illetve műszaki állapotuk, valamint készleteik feltöltöttsége, ami meghatározza pillanatnyi harcértéküket. Ugyanakkor rajba szervezett drónok a harctámogató tevékenységek mellett felhasználhatók akár védelmi és támadó feladatok során is.

A pilóta nélküli légi eszközök több évtizedes története során jól megfigyelhető, hogy az egyes háborús konfliktusok, illetve a technológiai fejlődés milyen hatással voltak az eszközrendszer és alkalmazások fejlődésének irányára és ütemére. Mára a hadipari kutatások egyik súlypontja szintén az SUAV-k rajban történő alkalmazása eszközrendszerének fejlesztése körül látszik kialakulni, az abban rejlő lehetőség felismerésének köszönhetően. 2016. október 25-én, az amerikai légierő Mojave-sivatagban található China-Lake kísérleti támaszpontján került sor az egyik legismertebb kísérletre, ahol sikeresen hajtottak végre tesztet egy több mint 100 tagú UAV-rajjal. A gyakorlat során 3 db F/A-18 Super

12. ábra. Perdix raj a negyedik küldetés végrehajtása közben ${ }^{18}$

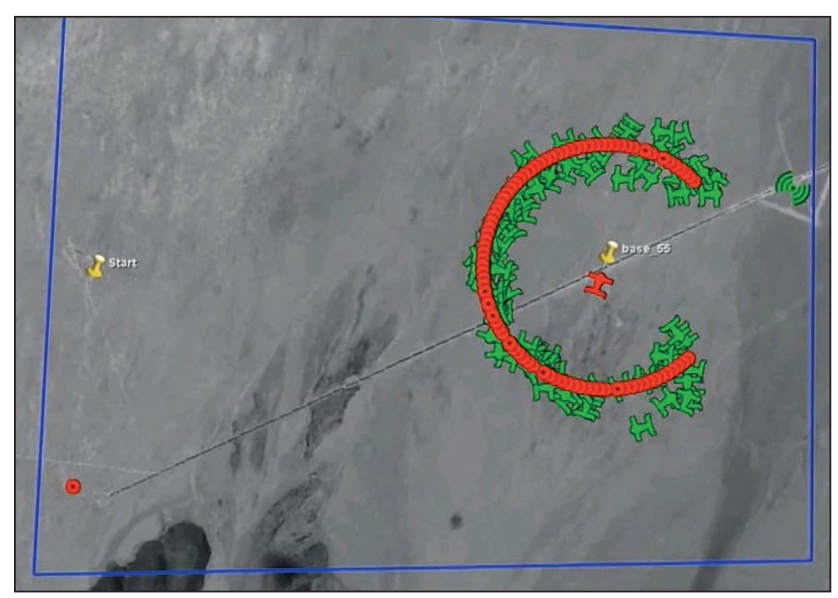

Hornet vadászgép szárnyai alá felerősített gondolákból öszszesen 103 db Perdix mini UAV-t szórtak ki, amelyek a levegőbe jutást követően önállóan rajba szerveződtek, kialakították egymás között a kommunikációs csatornákat és végrehajtottak 4 egyszerü küldetést. Ebből három feladat egy megadott célpont feletti körözés, míg a negyedik egy 100 m átmérőjű kör formájú alakzat kialakítása volt, mint az a 12. ábrán is látható. A gyakorlat jelentősége abban állt, hogy a bevetési környezet komplexitása miatt, a korábbiaktól eltérő módon a rajban nem programmal előre szinkronizált egyedek vettek részt, hanem kollektív szervezetet alkotva "közös tudattal” és döntéshozatali mechanizmussal rendelkeztek, amivel adaptív módon, közvetlen emberi beavatkozás nélkül tudták végrehajtani a különböző repülési feladatokat. A kollektív tudat szükségességét a vezető egyed hiánya indokolta. A raj minden tagja egyenrangú félként vett részt a feladatok végrehajtásban, így az egyes egyedek elvesztése sem tudta megakadályozni az eredeti terv kivitelezését [33][34]. A továbbiakban a mini, pilóta nélküli légijármü rajok katonai felhasználásának lehetőségeit három alkalmazási terület köré csoportosítva ismertetjük.

\section{MINI, PILÓTA NÉLKÜLI LÉGIJÁRMŰ RAJ TÁMADÁSBAN TÖRTÉNŐ ALKALMAZÁSA}

A mini UAV-rajokat támadásban elsősorban precíziós csapásmérés során lehet hatékonyan akár közvetve, akár közvetlenül felhasználni. Közvetett alkalmazás során az egyes egyedeket, vagy azok csoportjait távolabbról, közvetlenen közelről, esetleg a céltárgyra történő landolással, lézeres (optikai) vagy rádiófrekvenciás célmegjelölésre, rávezetésre lehet felhasználni a támadófegyverek pontos célba-juttatásának támogatása érdekében. Közvetlen alkalmazás esetén maguk az egyedek hajtják végre a támadást, robbanótöltetek hordozásával és elműködtetésével. A hagyományos kazettás bombák működési elvén alapuló fegyver hatékonysága a sokszorosára növelhető, ha a testból kivetett általános robbanótöltetek helyett kisebb méretű robbanószerrel megrakodott drónokat szórnak ki. A hagyományos kazettás bomba töltetei véletlenszerǔen csapódnak be a támadott területen, míg az SUAV-raj egyedei repülés közben beazonosítják és elosztják egymás között a célpontokat, majd rávezetik magukat azok leginkább sebezhető pontjára. A célpont fontosságától, típusától és védelmi képességétől függően az egyes egyedek adaptív módon koncentrálhatják is pusztító erejüket a becsapódások térben és időben történő szinkronizálásával. „Humánus" hadviselés esetén az élőerő ellen bevetett kis méretű koncentrált töltetű drónok úgy is programozhatók, hogy nem halálos fegyverként csak megsebesítsék, vagy más módon harcképtelenné tegyék (pl. elektromos vagy akusztikus sokk) az ellenséges katonákat. Tehát az ilyen támadó rajok minden tagja tartalmaz egy meghatározott mennyiségű robbanószert, amivel eltalálva célpontját megsemmisíti vagy harcképtelenné teszi azt, emiatt ezeket az eszközöket „intelligens lőszereknek” is nevezik. Rendszerint ezek nagyfelbontású kamerával felszereltek, ami az infravörös tartományban is érzékel, ezzel - még a csapás kiváltása előtt - biztosítva a célpont lehető legpontosabb azonosításának lehetőségét. Az ilyen drónrajokat a jövőben várhatóan egyre nagyobb arányban alkalmazzák háborús konfliktusokban, mivel magas precizitású támadások végrehajtására alkalmasak, amivel a járulékos károk mértéke, civil áldozatok száma minimalizálható [35]. Ugyanakkor előállításuk költsége is csökkeni fog, így alkalmazásuk gazdaságosabb is lehet, mint a nagy pusztító erejű fegyverek töme- 
ges alkalmazása. Mivel összeségében lényegesen kevesebb robbanóanyag felhasználása elegendő a hagyományos fegyverekkel azonos hatás eléréséhez, drasztikusan csökken a járulékos pusztítás mértéke, így a konfliktust követő helyreállítási munkálatok költségeinek jelentős mérséklődésére is lehet számítani. Szintén a kisebb pusztításnak köszönhetően a polgári lakosság bizalmának későbbi megnyerésére is várhatóan csekélyebb erőfeszítést kell majd fordítani a civil-katonai együttműködési (CIMIC Civil-Military Co-operation) tevékenységek során. Ugyanakkor drónrajokat támadó és védelmi tevékenységek során egyaránt igénybe lehet venni a pszichológiai, lélektani múveletek (PSYOPS - Psychological Operations) speciális eszközeként, az ellenség megtévesztése, félrevezetése vagy akár megfélemlítése céljából (tömeges alkalmazás, fokozott fény és hanghatások, pirotechnikai megoldások).

\section{MINI, PILÓTA NÉLKÜLI LÉGIJÁRMÜ RAJ VÉDELEMBEN TÖRTÉNŐ ALKALMAZÁSA}

Az SUAV-rajok felhasználása védelemben számos területen, illetve feladat végrehajtása során indokolt lehet. Egyrészt a fenti módszerek alkalmazhatók közvetlenül a támadók ellen, de az ilyen rendszerek felhasználhatók elektronikai megtévesztésre és csalicélként is. Az alkalmazás másik nagy területe az objektum- és táborvédelem komplex feladatrendeszre lehet.

Csalicélként történő alkalmazás esetén hasonló hatás érhető el, mint akár egy szögvisszaverő alkalmazása esetén azáltal, hogy egy besugárzott radarjel vételét követően azt úgy sugározza vissza, hogy nagyobb kiterjedésű, vagy több célpontként jelenjen meg az indikátoron, ezáltal megtévesztve az ellenséget. Ezzel lehetőség van akár értékesebb célok elrejtésére, az ellenség tűzereje egy részének ideiglenes lekötésére, vagy különböző légi műveletek imitálásával annak elterelésére. Ugyanakkor vadászgépek, bombázók, vagy szállítógépek önvédelmi képessége is növelhető azáltal, hogy az ellenséges légvédelem tűzerejét elterelik magukról csalicélként használt drónrajok kibocsátásával, miközben a légvédelmi fegyverek felfedve magukat, támadhatóvá válnak.

Mini UAV-rajok alkalmasak lehetnek pilóta nélküli légijármű-támadások elhárítására is, oly módon, hogy az egyedek „kamikaze” eljárást alkalmazva belecsapódnak a védendő légtérbe behatoló gépbe. Ezzel a megoldással kiegészítve a laktanyák, táborok, vezetési pontok, légvédelmi állások, rakétaindító állványok, repülőterek, kikötők, raktárak és más objektumok védelmi rendszerét, jelentősen fokozható azok biztonsága. Ugyanakkor statisztikai számításokkal az is igazolható, hogy egy SUAV-rajjal végrehajtott támadás ellen a leghatékonyabb védelmet egy másik mini drónraj védelmi célú alkalmazása jelentheti. Ez a megállapítás komoly verseny képét vetítheti előre a drónrajok területén, amelyben azok kerekednek majd felül, akik a leghatékonyabb algoritmusokkal tudják biztosítani rajuk számára a legmagasabb szintű intelligenciát, illetve hatékonyan használják azokat komplex rendszerben más drónelhárítási módszerekkel (pl. elektromágnes, fizikai védelem, pusztítás) együtt [36][37].

\section{MINI, PILÓTA NÉLKÜLI LÉGIJÁRMŰ RAJ TÁMOGATÓ TEVÉKENYSÉGEK SORÁN TÖRTÉNŐ ALKALMAZÁSA}

A mini UAV-rajok kiemelkedő szerephez juthatnak a jövő harctámogató tevékenységeinek sorában is. Kis méretük, mozgékonyságuk miatt hatékonyan használhatók harci kutató és mentő (CSAR - Combat Search and Rescue) műveletek során, legyen szó akár egy harcoló alegység néhány elszigetelt tagjáról, egy, az ellenséges vonalak mögött megsérült felderítőről, vagy egy lelőtt vadászgép pilótájáról. Az egyedszám emelésével arányosan növekszik az időegység alatt átvizsgálható terület nagysága, így a keresett személyek felfedezésének valószínűsége is. A keresett személy helyének azonosítását követően a raj lehetőséget biztosíthat kétirányú kommunikációs kapcsolat kialakítására, illetve a túlélési valószínűség növeléséhez szükséges felszerelések, eszközök eljuttatására. Kis méretüknek köszönhetően nehéz a raj egyedeit felderíteni, illetve pusztítani, így aránylag biztonságosan repülhetnek be veszélyes területekre is [36][37].

A következő támogatási tevékenység, amit képesek vagyunk hatékonyan elvégezni SUAV-rajok segítségével, a felderítés. Az ISR jelenleg is az a terület, amelyben a legnagyobb arányban jellemző a pilóta nélküli eszközök alkalmazása. Hasznos teherként a raj egyes tagjaira különböző kamerák, szenzorok is elhelyezhetők, így a multispektrális felderítési, illetve megfigyelési képesség ilyen módon is kialakítható, akár az egyes spektrumtartományokért felelős dróncsoportok létrehozásával. Ennek megfelelően a rajon belül opcionálisan lehetnek rádióelektronikai felderítést (SIGINT - Signal Intelligence), képi felderítést (IMINT - Image Intelligence), vagy műszeres felderítést (MASINT - Measurement Intelligence), illetve harci kárbecslést (BDA - Battle Damage Assessment) végző csoportok. Esetenként célszerű lehet a raj egyes tagjait célrávezető, vagy közvetlen támadó képességgel is ellátni arra az esetre, ha a felderítés során azonnali beavatkozás válik szükségessé akár raj-önvédelmi okból, akár a magasabb prioritású cél megsemmisítése érdekében. Nagyobb pusztító erejű csapás esetén a raj csak célmegjelölést végez, míg a csapást harcászati, vagy hadászati színtű támadó UAV hajtja végre. A mini UAV-rajok jól használhatóak kis alegység szinten is, mivel egyszerü szerkezetűek, könnyen hordozhatók, így a katonák alapfelszerelésnek részét képezhetik. Alkalmazásuknak köszönhetően a harcoló alegységek folyamatosan frissülő független helyzetismerettel (SA - Situational Awarness) rendelkezhetnek [36][37].

\section{Összegzés}

A különböző eszközök és rendszerek katonai alkalmazásainak elmúlt évtizedes tendenciáit elemezve megállapíthatjuk, hogy egyes területekre, így a pilóta nélküli légijárművekre is, a hadipari fejlesztések mellett polgári célú kutatások eredményei egyre nagyobb hatást gyakorolnak. Különösen igaz ez a SUAV-rajokra, ahol a hadipari fejlesztések csaknem közvetlenül a kereskedelmi célú fejlesztésekkel versenyeznek, amelynek következtében a közeljövőben jelentős előrelépés várható a katonai alkalmazások területén is.

Ugyanakkor mindenképpen meg kell jegyezni, hogy jelenleg a rajintelligenciát biztosító algoritmusok fejletlensége miatt, ezek a megoldások csak korlátozottan vehetők igénybe gyakorlati feladatok végrehajtása során. Azonban a mesterséges intelligencia térnyerésével, és az öntanuló algoritmusok gyors fejlődésével, illetve a tömeges gyártás költségeinek gyors csökkenésével hamarosan olyan, a cikkben is ismertetett többszintű, komplex megoldások állnak majd a hadviselő felek rendelkezésére, amelyeknek köszönhetően teljesen új alapokra kell helyezni a harcászati elveket és a teljes eljárásrendet, de valószínűsíthetően a magasabb vezetési szinteken is komoly változásokra lehet majd számítani. A rajokat a drónok csökkenő mérete mel- 
lett az egyre nagyobb egyedszám, magasabb szintű kollektív intelligencia, és túlélőképesség, kifinomult kommunikációs eljárások, valamint a műveleti területre történő kijuttatás egyre változatosabb formái (pl. tüzérségi eszközből kilőtt lövedékben, kazettás bombában, vadászgépről, vagy hadászati drónról kiszórva, vagy ledobott konténerből kirajzva), illetve a szárazföldi és vízi botokkal történő komplex alkalmazások fogják jellemezni. A 21. század második feléhez közeledve ez a technológia egyre meghatározóbb szerepet kap a hadviselés minden formájában és színterén, a robothadseregek korszakáig vezető út során.

\section{IRODALOMJEGYZÉK}

[30] Ehang.com. „EHang Egret's 1374 drones dancing over the City Wall of Xi'an, achieving a Guiness World Records title." Letöltés ideje: 2018.05.04. http://www.ehang.com/news/365.html;

[31] „The first practical drone for farmers.” Letöltés ideje: 2018.05.10. http://www.american-robotics.com/;

[32] Alderton, Matt. „To the Rescue! Why Drones in Police Work Are the Future of Crime Fighting." Letöltés ideje: 2018.05.13. https://www.autodesk.com/redshift/drones-in-police-work-future-crime-fighting/;

[33] Mizokami, Kyle. „The Pentagon's Autonomous Swarming Drones Are the Most Unsettling Thing You'll See Today." Letöltés ideje: 2018.05.16.

https://www.popularmechanics.com/military/aviation/a24675/pentagon-autonomous-swarming-drones/;

[34] „Perdix fact sheet.” Letöltés ideje: 2018.05.16. https://www.defense.gov/Portals/1/Documents/pubs/Perdix\%20Fact\%20Sheet.pdf;

[35] Powers, Benjamin. „How Intelligent Drones Are Shaping the Future of Warfare.” , Letöltés ideje: 2018.05.22. https://www.rollingstone.com/culture/features/how-intelligent-drones-are-shaping-the-future-of-warfare-w471703;

[36] United States Air Force. „RPA Vector, Vision and Enabling Concepts 2013-2038.” Letöltés ideje: 2018.05.27. http://www.af.mil/Portals/1/documents/news/USAFRPAVectorVisionandEnablingConcepts2013-2038.pdf;

[37] U.S. Air Force. „Small Unmanned Aircraft Systems (SUAS) Flight Plan: 2016-2036.” Letöltés ideje: 2018.05.27. http://www.af.mil/Portals/1/documents/isr/Small_UAS_Flight_Plan_2016_to_2036.pdf.

\section{JeGYZETEK}

15 Szerzői szerkesztés https://www.youtube.com/watch?v=4mHDDG3FCjs alapján, szerkesztés ideje: 2018.05.04.

16 Szerzői szerkesztés https://www.youtube.com/watch?v=mUeyfLIGtLQ alapján, szerkesztés ideje: 2018.05.10.

17 Szerzői szerkesztés https://www.youtube.com/watch?v=7qxRTRXsHW0 alapján, szerkesztés ideje: 2018.05.13.

18 Szerzői szerkesztés https://www.youtube.com/watch?v=bsKbGc9TUHc alapján, szerkesztés ideje: 2018.05.16.

\section{Udovecz György}

\section{0-1945 magyar gyalogos katonáinak öltözete, felszerelése és fegyverzete}

\section{A magyar katona - Segédanyag katonai hagyományőrzők részére}

A trianoni diktátum értelmében 1920. június 4. után megszüntették az általános hadkötelezettséget, és Magyarország számára csak az önkéntes belépés és kiegészítés alapján álló, 35 ezer főt - ebből 1750 tiszt - meg nem haladó létszámú hadsereget engedélyezetek. A Magyar Királyi Honvédségnek nem lehetett légi és folyami hadereje, nem tarthatott rendszerben nehéztüzérséget, páncélozott harcjárműveket, légierőt, illetve vegyi és támadó jellegű műszaki egységet. A Nemzetgyűlés 1921 novemberében elfogadta a rejtett katonai kiképzést célzó törvénycikket, és ettől az időtől több rejtett katonai szervezetet is létrehoztak. A nyílt és rejtett alakulatok együttes létszáma 1930-ban már több mint 57 ezer fő volt, és 1932-től (még mindig titokban) megkezdték az általános védkötelezettségen alapuló fegyveres erő kiépítését. Az 1938. augusztus 29-i bledi egyezmény megkötését követően - amelyben Magyarország lemondott az elcsatolt területek visszafoglalásáról - újra fejlesztésbe kezdhetett a hadiipar. Az első és második világháborúban a gyalogságnak sorsdöntő szerepe volt a csaták kimenetelében. Ez idő alatt, a magyar katonák mindig olyan öltözetet viseltek, amely kifejezte a Magyar Királyi Honvédséghez való tartozásukat. Ezen hordták felszerelésüket és fegyverzetüket, kitüntetéseiket és jelvényeiket. A gyalogság egyenruházata, felszerelése, fegyverzete egy kis része a hadtörténelemnek, mégis rengeteg kép, fotó és rajz ad átfogó képet erről a korszakról. A könyvet történészeknek, muzeológusoknak, levéltárosoknak, könyvtárosoknak, régészeknek, továbbá iskolásoknak ajánljuk, hogy megismerhessék, és jobban megérthessék a múltnak ezen szeletét. Ajánljuk továbbá a katonai hagyományőrzők számára, és nem utolsósorban jelen korunk katonáinak. (W. T.)

A Zrínyi Kiadó által 2019-ben megjelentetett keménytáblás, számos fotóval illusztrált könyv terjedelme 159 oldal. 4800 Ft-os áron kaptaható a könyvesboltokban, illetve közvetlenül a Zrínyi Kiadótól is, 20\%-os helyszíni kedvezménnyel. Cím: 1087 Budapest, Kerepesi út 29/b, (tel.: 06 1-459-5373, e-mail: gyoredina@armedia.hu). 